\title{
Contents of chemical elements in tissues of European badger (Meles meles) affected by ovarian tumour - a case report
}

\author{
Karel Bukovjan ${ }^{1}$, Aleš Toman², Karel Kutlvašr ${ }^{3}$, Petr Marada ${ }^{4}$, Roman Kodet \\ Petr Sláma ${ }^{6}$, Libor Křikava ${ }^{3}$
}

\author{
${ }^{1}$ Forestry and Game Management Research Institute, Strnady, Czech Republic \\ ${ }^{2}$ Czech University of Life Sciences Prague, Department of Ecology, ${ }^{3}$ Department of Game Management \\ and Wildlife Biology, Prague, Czech Republic \\ ${ }^{4}$ Mendel University in Brno, Department of Agriculture, Food and Environmental Engineering, \\ Brno, Czech Republic \\ ${ }^{5}$ Charles University in Prague and University Hospital Motol, Department of Pathology \\ and Molecular Medicine, $2^{\text {nd }}$ Faculty of Medicine, Prague, Czech Republic \\ ${ }^{6}$ Mendel University in Brno, Department of Animal Morphology, Physiology and Genetics, \\ Brno, Czech Republic \\ Received January 30, 2014 \\ Accepted April 24, 2014
}

\begin{abstract}
Higher concentrations of chemical elements in animal tissues may be associated with tumours and may explain cancerogenity. In this study, selected chemical elements were measured in the liver, kidneys, muscles and tissues affected by tumour in a dead female European badger (Meles meles) with a metastatic ovarian carcinoma. Atomic absorption spectroscopy was used for the assessment of concentrations of arsenic, cadmium, chromium, copper, lead, and zinc. AMA 254 analyser was used for the assessment of mercury concentration. Concentrations of heavy metals such as $\mathrm{As}, \mathrm{Cr}, \mathrm{Cu}, \mathrm{Zn}, \mathrm{Cd}, \mathrm{Pb}$, and total $\mathrm{Hg}$ amounted to $0.031,0.16,7.74,44.54$, $0.67,0.67$, and $0.36 \mathrm{mg} \cdot \mathrm{kg}^{-1}$ in the tumour tissue. This is the first detection of ovarian tumour in a European badger (Meles meles) which was systematically examined for the presence of chemical elements.
\end{abstract}

Heavy metals, hazardous elements, cancerous tissue, ovary

A relatively low prevalence of tumorous diseases has been reported in game animals in the Czech Republic. For example, histopathology revealed benign and malignant tumours in European hare (Lepus europaeus), roe deer (Capreolus capreolus), fallow deer (Dama dama) and red fox (Vulpes vulpes) (Bukovjan and Karpenko 1990; Karpenko and Bukovjan 1992; Karpenko and Bukovjan 1995; Bukovjan et al. 2011). Considering small mammals, findings of ovarian adenofibroma in bank vole (Myodes glareolus; formerly Clethrionomys glareolus) from the Tatra National Park are noteworthy (Bukovjan et al. 1995).

Malignant ovarian serous carcinoma tumour, classified in accordance with the International Classification of Diseases for Oncology ICD-O 8460/3, ovaria code C56.9 was diagnosed in an adult badger (Meles meles) in 2011. This tumour was found in an animal showing typical tumorous cachexy; other lesions were detected in serous, fibrous and adipose tissues of the abdominal cavity, muscles of diaphragm and lungs. Selected chemical elements (i.e., arsenic, cadmium, chromium, copper, mercury without definition of the chemical form, lead and zinc) were detected in several tissues as well as in the tumour.

The aim of this study was to detect some essential and hazardous chemical elements in tissues of a badger with a very rare type of tumour which is histologically and imunohistochemically identical to the fatal disease in humans.

Address for correspondence:

MVDr. Karel Kutlvašr

Czech University of Life Sciences

Department of Game Management and Wildlife Biology

Kamýcká 12916521 Praha 6 - Suchdol 


\section{Materials and Methods}

The specimen used in the present study included a fresh cadaver of a European badger female obtained in September 2011 (Přibyslav, Havlíčkův Brod District, Czech Republic). The body weight was $5.9 \mathrm{~kg}$. The age was estimated to be over 5 years. Skull measurements were $143 \mathrm{~mm}$ (width) and $83 \mathrm{~mm}$ (length). By the wear of teeth and adhesion lines of the mandible it was apparent that the animal was 5 to 6 years old.

Samples of $10 \times 10 \mathrm{~mm}$ in size (with tumour including metastasis) for histopathological examination were fixed in $10 \%$ neutral buffered formalin. After that, samples were prepared in a routine paraffin method and stained using haematoxylin-eosin, mucikarmin and periodic acid-Schiff method (PAS).

Selected chemical elements were determined in tissues following homogenization and mineralization using wet flame ashing for atomic absorption spectroscopy (AAS) (Varian Spectr AA 30 P, Varian, Australia). Mercury was detected using the AMA 254 analyser (Altec, Czech Republic) without mineralization.

Samples were analysed at the Forestry and Game Management Research Institute (Strnady, Czech Republic), Veterinary infirmary for small animal and game - laboratory, biomonitoring (Přibyslav, Czech Republic) and the Department of Pathology and Molecular Medicine, the $2^{\text {nd }}$ Faculty of Medicine, Charles University in Prague and University Hospital Motol (Prague, Czech Republic).

\section{Results}

The examined badger was severely cachectic, dehydrated, and showing slight ascites. On palpation, the liver was firm with a taut capsule. Sporadic haemorrhage was found under the capsule of liver. The lungs were enlarged and oedematous. In the lung parenchyma, there were gray-white miliary lesions.

The ovaries were soft in the section and generally enlarged with an irregular structure. Metastases were found in fibrous and adipose tissues and also in the serosa of the peritoneal cavity, diaphragmatic muscles and lungs. Extensive lymphangio invasion was present. As shown by histopathology, the ovarian tissue was destroyed (Plate I, Fig. 1). Ovarian stroma tissue with sporadic follicular cells was found on the surface of the tumorous mass. The tumour structure was cyst papillary. Foci of solid tumour tissue with cribriform and tubular structure were seen to form locally. The proper tumour cells were low cylindrical with homogenous and slightly basophilic cytoplasm. Nuclei of cells were round in shape, uniform with fine chromatin and central or off-centrally located nucleolus. The mitotic activity was sporadic. Sporadic small calcospherits were within the slim fibrovascular stroma of papillae without fibroplasia. Metastases with lymphangio invasion occurred frequently. These were located primarily in the peritoneal cavity in the form of surface implants on the serosa, in fibrous and adipose tissues, and in muscles of diaphragm. A similar structure was found in the lung metastases (Plate II, Fig. 2).

Selected chemical elements were measured in the tissues of the badger with the abovedescribed tumorous changes. The highest concentrations of arsenic were detected in the liver compared to kidneys, muscles of diaphragm, and the tumour. Cadmium was most accumulated in the kidneys. The tumorous tissue contained relatively high contents of copper and zinc. Comparison of concentrations of measured elements in different tissues is shown in Table 1.

Table 1. Concentrations of chemical elements in tissues of badger (Meles meles) with ovarian tumour (ICD-O $8460 / 3)\left(\mathrm{mg} \cdot \mathrm{kg}^{-1}\right)$.

\begin{tabular}{lccccccc}
\hline \multirow{2}{*}{ Tissue } & \multicolumn{9}{c}{ Elements } \\
\cline { 2 - 8 } & $\mathrm{As}$ & $\mathrm{Cd}$ & $\mathrm{Cr}$ & $\mathrm{Cu}$ & $\mathrm{Hg}$ & $\mathrm{Pb}$ & $\mathrm{Zn}$ \\
\hline Liver & 0.07 & 1.09 & 0.46 & 9.67 & 0.49 & 2.98 & 36.20 \\
Kidneys & 0.02 & 2.06 & 0.31 & 5.81 & 0.67 & 1.69 & 28.30 \\
Muscle of diaphragm & 0.02 & 0.10 & 0.12 & 0.17 & 0.01 & 0.26 & 17.31 \\
Tumour & 0.03 & 0.67 & 0.16 & 7.74 & 0.36 & 0.67 & 44.54 \\
\hline
\end{tabular}




\section{Discussion}

Tumours are indisputably an important group of risk diseases that are relatively often reported from human oncology and veterinary pathology. The World Health Organization statistics reveal relatively high frequency of tumours in human population. Annually, more than 5 million human deaths are registered world-wide. Twenty five percent of them die due to malignant tumours before they reach 50 years of age. Tumorous diseases occur very often in dogs and cats and less frequently in farm animals (Sforna et al. 2003; Yener et al. 2004; Hori et al. 2006).

Tumorous diseases of game animals are rather rare. Ovarian tumours of hares have previously been analysed by Flux (1965) and Hoffmann and Morl (1985). Case reports of tumours of roe deer, hare and fallow deer in the Czech Republic were presented by Karpenko and Bukovjan (1992a; 1995), Bukovjan and Karpenko (1990) and Bukovjan and Karpenko (1996). Of much interest are ovarian metastases of adenocarcinoma of abomasum and uterus in Cervus elaphus nelsoni (Duncan et al. 2007). Tumours of predators were analysed on a separate basis (Karpenko and Bukovjan 1992b; Bukovjan et al. 2011). Benign ovarian tumour was diagnosed in a bank vole (Clethrionomys glareolus) from Slovakia (Bukovjan et al. 1995). Detection of chemical elements in game afflicted by tumours classified by the ICD-O system was done by Bukovjan and Karpenko (1996) and also as a correspondence of tumours diagnosed in human and veterinary pathology (Karpenko and Bukovjan 1992c). The prevalence of tumours in the Czech Republic is $1.682 \%$ in European hares (Bukovjan et al. 2011a) and $1.049 \%$ in red fox (Bukovjan et al. 2011b). The badger represents, similar to other predators, a paradigmatic species for development of ecological and behavioural research (Stopka and Johnson 2000). Predator pressure on handicapped and diseased individuals causes low incidence of tumorous diseases in their populations. The weakening of organism usually results in a subsequent death, in case of mustelids in their burrow. Tumorous diseases of badgers have not yet been monitored in the Czech Republic. Description of incidence of mediastinal lymphoma in this species comes from Italy (Mutinelli et al. 2004).

Table 2. Chemical elements in tissues $\left(\mathrm{mg} \cdot \mathrm{kg}^{-1}\right)$ of game animals with malignant tumours (Bukovjan and Karpenko 1996; reprinted with permission from Veterinářství).

\begin{tabular}{|c|c|c|c|c|c|c|c|}
\hline \multirow{2}{*}{ Tissue } & \multicolumn{7}{|c|}{ Elements } \\
\hline & As & $\mathrm{Cd}$ & $\mathrm{Cr}$ & $\mathrm{Cu}$ & $\mathrm{Hg}$ & $\mathrm{Pb}$ & $\mathrm{Zn}$ \\
\hline \multirow[t]{4}{*}{ Liver } & 0.01 & 0.80 & 0.60 & 20.60 & 0.02 & 2.50 & 32.30 \\
\hline & 0.03 & 1.25 & 0.37 & 7.93 & 0.01 & 1,00 & 26.28 \\
\hline & 0.04 & 0.96 & 0.43 & 12.60 & 0.02 & 0.89 & 26.06 \\
\hline & 0.04 & 0.37 & 0.22 & 7.17 & 0.05 & 0.24 & 26.30 \\
\hline \multirow[t]{4}{*}{ Kidneys } & 0.02 & 1.10 & 1,00 & 6.70 & 0.04 & 1.70 & 34.40 \\
\hline & 0.03 & 2.47 & 0.17 & 9.16 & 0.05 & 0.51 & 19.78 \\
\hline & 0.03 & 1.24 & 0.29 & 8.96 & 0.05 & 0.63 & 20.17 \\
\hline & 0.05 & 0.62 & 0.17 & 5.12 & 0.19 & 0.37 & 19.26 \\
\hline \multirow[t]{4}{*}{ Tumour } & 0.04 & 0.59 & 0.30 & 10.98 & 0.02 & 0.94 & 47.30 \\
\hline & 0.02 & 0.14 & 0.19 & 2.86 & & 0.50 & 44.36 \\
\hline & 0.02 & 0.17 & 0.17 & 3.20 & & 0.47 & 49.83 \\
\hline & 0.03 & 0.58 & 0.38 & 3.64 & 0.06 & 0.31 & 40.26 \\
\hline
\end{tabular}


Table 3. Chemical elements in tissues $\left(\mathrm{mg} \cdot \mathrm{kg}^{-1}\right)$ of game animals with benign tumours (Bukovjan and Karpenko 1996; reprinted with permission from Veterinářství).

\begin{tabular}{|c|c|c|c|c|c|c|c|}
\hline \multirow{2}{*}{ Tissue } & \multicolumn{7}{|c|}{ Elements } \\
\hline & As & $\mathrm{Cd}$ & $\mathrm{Cr}$ & $\mathrm{Cu}$ & $\mathrm{Hg}$ & $\mathrm{Pb}$ & $\mathrm{Zn}$ \\
\hline \multirow[t]{4}{*}{ Liver } & 0.03 & 0.13 & 0.16 & 6.86 & 0.01 & 0.16 & 21.77 \\
\hline & 0.09 & 0.72 & 0.17 & 14.36 & 1.26 & 0.61 & 32.60 \\
\hline & 0.07 & 0.83 & 0.20 & 9.09 & 1.03 & 0.49 & 36.11 \\
\hline & 0.06 & 0.65 & 0.16 & 6.34 & 0.03 & 0.17 & 30.16 \\
\hline \multirow[t]{5}{*}{ Kidneys } & 0.02 & 2.39 & 0.29 & 5.78 & 0.28 & 0.81 & 25.19 \\
\hline & 0.04 & 0.16 & 0.14 & 4.24 & 0.02 & 0.29 & 24.06 \\
\hline & 0.03 & 1.68 & 0.16 & 7.29 & 1.81 & 0.53 & 29.34 \\
\hline & 0.04 & 1.39 & 0.17 & 6.92 & 1.42 & 0.41 & 30.84 \\
\hline & 0.05 & 0.79 & 0.18 & 4.97 & 0.04 & 0.09 & 25.93 \\
\hline \multirow[t]{5}{*}{ Tumour } & 0.02 & 0.93 & 0.77 & 8.21 & 0.02 & 0.41 & 42.66 \\
\hline & & & 0.19 & 0.91 & 0.01 & 0.68 & 29.49 \\
\hline & 0.03 & 0.39 & 0.19 & 3.24 & 0.02 & 0.46 & 36.91 \\
\hline & 0.02 & 0.46 & 0.17 & 2.43 & 0.03 & 0.36 & 38.19 \\
\hline & 0.03 & 0.09 & 0.15 & 2.17 & & & 26.48 \\
\hline
\end{tabular}

Prevalence of tumorous cachexy, primarily in malignant and metastatic tumours, was described in another species of game. Hodgkin malignant lymphoma (code ICD-O 9654/3) was found in an adult 8-year-old roe deer with the weight of $8.20 \mathrm{~kg}$ (Karpenko and Bukovjan 1995); and a tumour (code ICD-O 8000/1) was found in an 11-year-old fallow deer (Bukovjan and Karpenko 1996). In our case, severe cachexy was also detected in the afflicted animal. Substantially higher body mass is normally reported in badger.

Selected chemical elements (arsenic, cadmium, chromium, copper, total mercury, lead and zinc) were detected in paucity of tumours in game in previous years (Bukovjan and Karpenko 1996). The mean concentration of zinc in malignant tumours $\left(45.43 \mathrm{mg} \cdot \mathrm{kg}^{-1}\right)$ was higher in comparison with benign tumours $\left(34.74 \mathrm{mg} \cdot \mathrm{kg}^{-1}\right)(P<0.05)$. Differences in concentrations of other elements were not significant. In comparison, higher concentrations of cadmium, chromium, copper and comparable concentrations of mercury, lead, zinc and arsenic were detected in the observed tumour (Tables 2 and 3). Higher concentration of hazardous elements can be affected by faster growth and proliferation of cells in connection with the occurrence of metallothioneins in tumours (Babula et al. 2012; Krizkova et al. 2012).

Detection of different concentrations of selected chemical elements in individual tissues afflicted by tumours presents an opportunity to enhance our understanding of oncological problems.

\section{References}

Babula P, Masarik M, Adam V, Eckschlager T, Stiborova M, Trnkova L, Skutkova H, Provaznik I, Hubalek J, Kizek R 2012: Mammalian metallothioneins: properties and functions. Metallomics 4: 739-750

Bukovjan K, Karpenko A 1990: Differentiated teratoma with prevalent structure of dermoid cyst in ovary of European hare (in Czech). Folia Venatoria 20: 331-335

Bukovjan K, Karpenko A, Chovancová B 1995: Ovary adenofibroma of bank vole (in Czech). Veterinářství 40: 165

Bukovjan K, Karpenko A 1996: Concentration of chemical elements in tumour of game classified by system ICD-O (in Czech). Veterináŕství 41: 423-425 
Bukovjan K, Kutlvašr K, Feureisel J, Ježek M, Havránek F 2011: Tumour incidence of red fox (Vulpes vulpes L.) (in German). Beitrage zur Jagd- und Wildforschung, Bd 36: 297-300

Duncan C, Powers J, Davis T, Spraker T 2007: Abomasal and uterine adenocarcinomas with ovarian metastasis in a captive elk (Cervus elaphus Nelsoni). J Vet Diagn Invest 19: 560-563

Flux JEC 1965: Incidence of ovarian tumors in hares in New Zealand. J Wildlife Manag 29: 622-624

Hoffman W, Morl C 1985: Dermoid cyst (in German). Zschr F Jagdwissenschaft 31: 184-186

Hori Y, Uechi M, Kanakubo K, Sano T, Oyamada T 2006: Canine ovarian serous papillary adenocarcinoma with neoplastic hypercalcemia. J Vet Med Sci 67: 979-982

Karpenko A, Bukovjan K 1992: Intraductal papillomatosis of the mammary gland of an eight-year deer (in German). Zschr fuer Jagdwissenschaft 38: 225-268

Karpenko A, Bukovjan K 1992: Complex odontoma of gum of red fox maxilla (V. vulpes L.) (in Czech). Veterináŕství 42: 421

Karpenko A, Bukovjan K 1992: Tumours of wildlife animals (In Czech). Ces Slov Patol 32: 78-83

Karpenko A, Bukovjan K 1995: Hodgkin's malignant lymphoma of adult roe deer (Capreolus capreolus L.) (in Czech). Veterinářství 40: 434-436

Krizkova S, Ryvolova M, Hrabeta J, Adam V, Stiborova M, Eckschlager T, Kizek R 2012: Metallothionein and zinc in cancer diagnosis and therapy. Drug Metab Rev 44: 287-301

Mutinelli F, Vascellari M, Melchiotti E 2004: Mediastina lymphoma in a badger (Meles meles). J WildlDis 40: $129-132$

Sforna M, Brachelente E, Lepri E, Mechelli L 2003: Canine ovarian tumours: A retrospective study of 49 cases. Vet Res Commun 27: 359-361

Stopka P, Johnson DP 2000: Badger (Meles meles) as a model species for the development of ecological and behavioural research. Lynx, Praha 31: 125-131

Yener Z, Karaca F, Alan M 2004: Serous papillary cystadenoma in the ovary of a cow. Aust Vet J 82 : 779-781 
Plate I

Bukovjan K. et al.: Contents of chemical... pp. 139-143

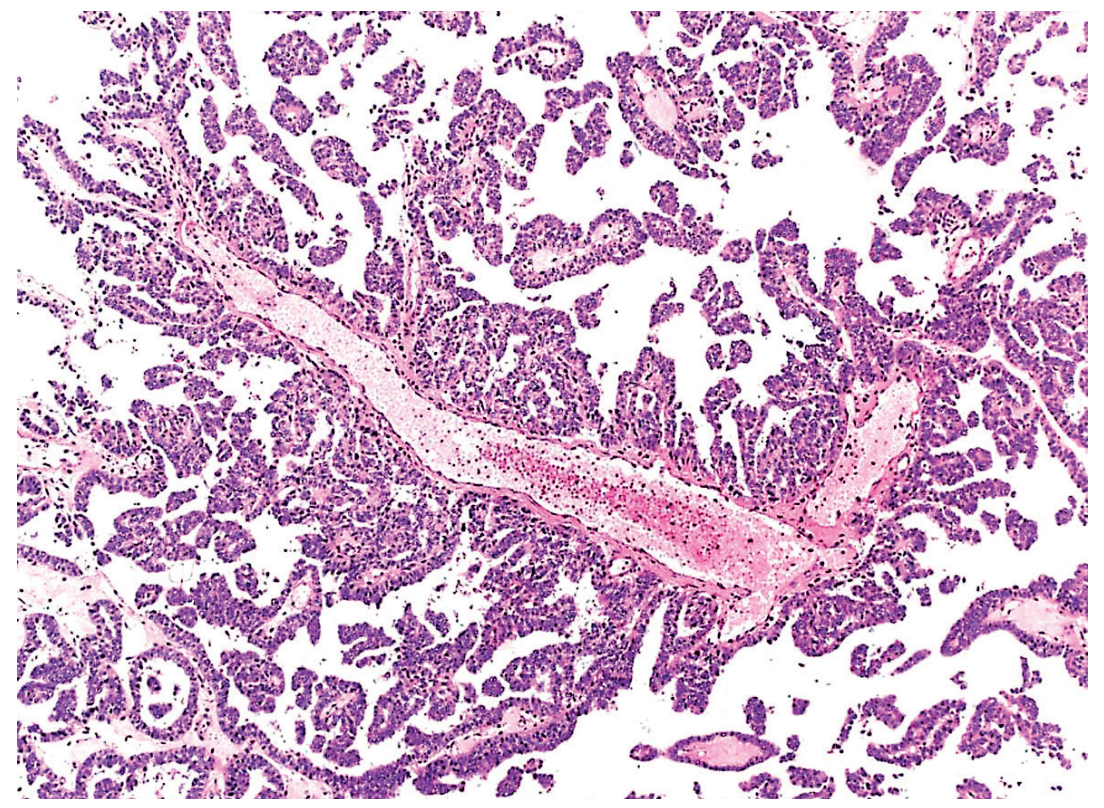

Fig. 1. Low grade papillary carcinoma of the ovary with a typical papilliferous growth pattern. The papillae lined by the neoplastic epithelial cells are attached to fibrovascular septae. Tissue section stained with haematoxylin and eosin; $\times 110$ magnification 


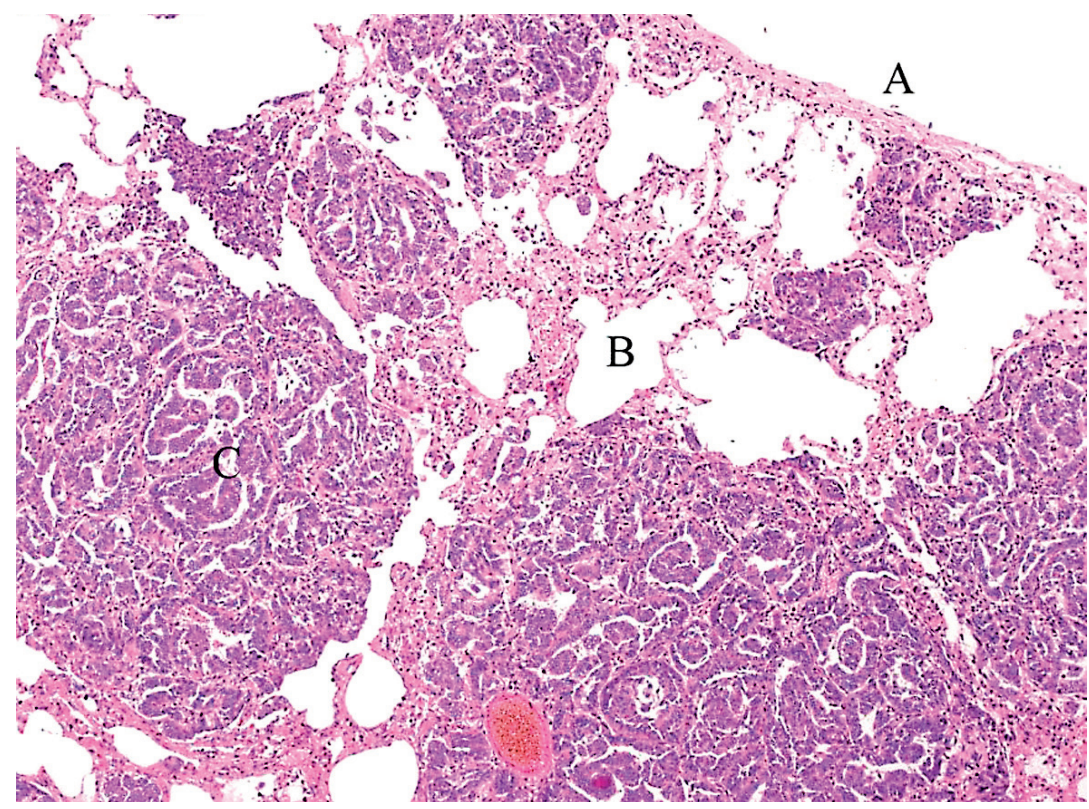

Fig. 2. Pulmonary metastatic disease. Pleural surface of the lung (A), the lung parenchyma itself with uninvolved alveoli (B), and a massive metastatic spread of the carcinoma with a destruction of the underlying lung tissue $(C)$. Again, the cyst papillary pattern of the carcinoma is maintained in the metastatic site. Tissue section stained with haematoxylin and eosin; $\times 110$ magnification 